\title{
Value Addition in Indian Agriculture: Indispensable Trajectory for Growth
}

\author{
Dr. B. NAGARJUNA \\ Associate Professor, Dept of Management Studies, Sree Vidyanikethan Institute of Management TIRUPATI \\ nagarjuna1975@gmail.com
}

\begin{abstract}
Agriculture employs 43.21 percent of India's workers and accounts for 14.6 percent of the country's GDP. The GVA of the primary sector fell progressively from 18.5 percent in 2011-12 to 17.2 percent in 2017-18. A decline in the average farm size of agricultural land has been observed. With various obstacles, including low productivity and poor output quality, India's food processing industry has huge potential to strengthen the country's rural economy. To thrive and profit from the agriculture sector, value addition solutions for agricultural items are essential. The researcher tries to solve this issue and identify potential areas for value addition in cultivational methods, food grain processing, and fruits and vegetable processing.

Keywords:Value addition, Gross Value Added (GVA), Gross Capital Formation (GCF), Contract farming, Cooperative farming,

DOI: $10.7176 / \mathrm{EJBM} / 14-4-06$

Publication date: February $28^{\text {th }} 2022$

\section{INTRODUCTION}

The agriculture sector in India accounts for $14.6 \%$ of the country's GDP and $43.21 \%$ of jobs (2018-19). Agriculture is the most significant sector from a socioeconomic standpoint, and it requires concentration and attention at all levels. The Indian government's objective of doubling farmer income by 2022 highlights the necessity to pursue all available methods of enhancing farmers' productivity and profitability(Consultation Paper on IDEA, 2021).
\end{abstract}

\subsection{GVA (Gross Value Added) of Agriculture \& Allied Sector}

According to the latest records, the contribution of the primary sector to the national GDP is listed in Table 1 and Figure 1 .

\begin{tabular}{|c|c|}
\hline \multicolumn{2}{|c|}{$\begin{array}{c}\text { able 1. Percentage Share of GVA of Agriculture and } \\
\text { Allied sector to Total Economy }\end{array}$} \\
\hline Year & Percentage \\
\hline $2011-12$ & 18.5 \\
\hline $2013-13$ & 18.2 \\
\hline $2013-14$ & 18.6 \\
\hline $2014-15$ & 18.2 \\
\hline $2015-16$ & 17.7 \\
\hline $2016-17$ & 17.9 \\
\hline $2017-18$ & 17.2 \\
\hline $2018-19$ & 17.6 \\
\hline $2019-20$ & 18.4 \\
\hline $2020-21$ & 20.2 \\
\hline Source: National Statistical Office (NSO), M/o Statistics \& PI \\
\hline
\end{tabular}

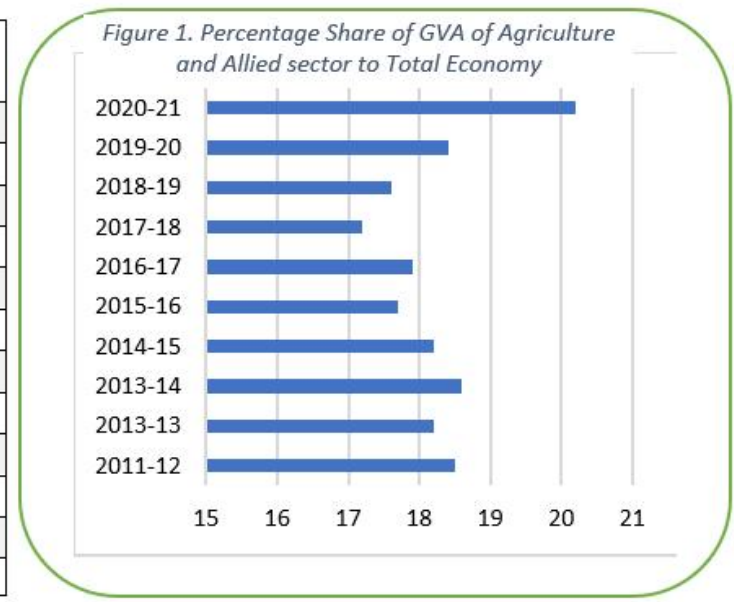

The primary sector's GVA gradually decreased from 18.5 percent in 2011-12 to 17.2 percent in 2017-18, before gradually increasing to 20.2 percent in $2020-21$.

\subsection{Investment in Agriculture}

Investment in (Rs Crore) in agriculture is presented in Table 2. The total investment is divided into public and private investments and provided from 2011-12 to 2016-17, 6-year period. 
Table 2. Public and Private Investment in Agriculture and Allied Sectors in Total GDP at Market Prices

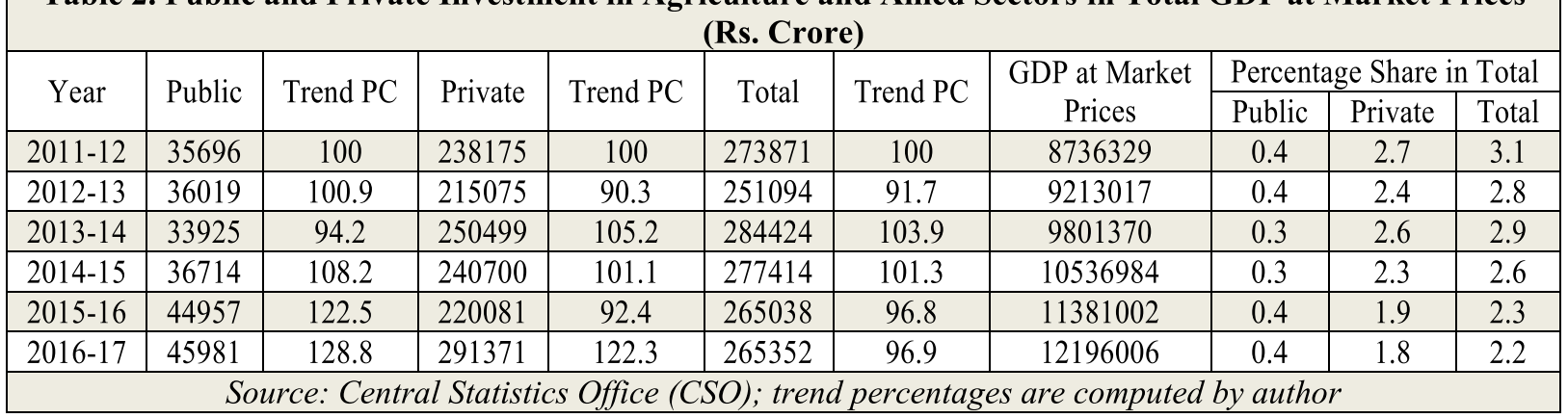

The trend percentages for each category and the total column are calculated and compared to the corresponding GDP (Gross Domestic Product) by displaying in percentages. Except for the year 2013-14, public investment is growing. Except for a brief blip in 2013-2014 and 2015-16, private investment has been steadily expanding. In 2016-17, there was a significant rise in investment. The trend in the total column is mostly consistent with the trend in private investment.

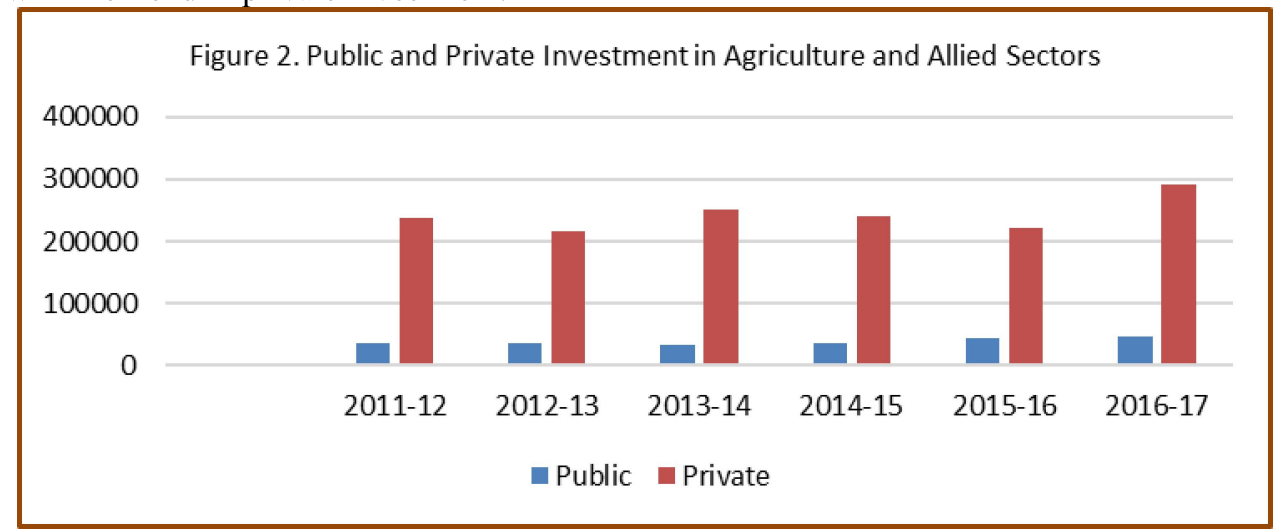

Agriculture investment is under 3\% of GDP. Agriculture investment by the government is less than $1 \%$ of GDP, whereas private investment ranges from 1.8 to 2.7 percent of GDP, with a downward tendency. Figure 2 illustrates the size of public and private investment.

\subsection{Share of Gross Fixed Capital Formation (GFCF)}

Table 3 illustrates the proportion of gross fixed capital creation in agriculture (including allied industries) in India, and the percentage is continuously declining in recent years.

\begin{tabular}{|c|c|c|c|c|c|c|c|c|c|}
\hline \multicolumn{10}{|c|}{ Table 3. Share of Gross Fixed Capital Formation } \\
\hline \multicolumn{1}{|c|}{ Year } & 2008 & 2009 & 2010 & 2011 & 2012 & 2013 & 2014 & 2015 & 2016 \\
\hline $\begin{array}{l}\text { GFCF as \% } \\
\text { Total GFCF in } \\
\text { the Nation }\end{array}$ & 8.64 & 8.62 & 7.72 & 8.25 & 7.4 & 8.52 & 7.65 & 7.35 & 7.16 \\
\hline $\begin{array}{l}\text { Trend } \\
\text { Percentage }\end{array}$ & 100 & 99.8 & 89.4 & 95.5 & 85.7 & 98.6 & 88.5 & 85.1 & 82.9 \\
\hline
\end{tabular}

The trend percentage is calculated using 2008 as the base year, and the downward trend can be seen beginning in 2014 .

\subsection{Share (\%) of Gross Capital Formation $(G C F)$ to GVA}

The share of GCF to the GVA in the primary sector is presented at 2011-12 prices as well as at current prices in Table 4. 


\begin{tabular}{|c|c|c|c|c|c|c|}
\hline \multicolumn{2}{|c|}{ Table 4. Percentage Share of GCF to GVA in Agriculture \& Allied Sectors } \\
\hline \multirow{2}{*}{ YEAR } & \multicolumn{3}{|c|}{ At 2011-12 Prices } & \multicolumn{3}{|c|}{ At Current Prices } \\
\cline { 2 - 7 } & Public & Private & Total & Public & Private & Total \\
\hline $2011-12$ & 2.4 & 15.9 & 18.2 & 2.4 & 15.9 & 18.3 \\
\hline $2012-13$ & 2.4 & 14.1 & 16.5 & 2.4 & 14 & 16.3 \\
\hline $2013-14$ & 2.1 & 15.6 & 17.7 & 2.1 & 15.1 & 17.2 \\
\hline $2014-15$ & 2.3 & 15 & 17.3 & 2.3 & 14.1 & 16.3 \\
\hline $2015-16$ & 2.8 & 13.6 & 16.4 & 2.8 & 12.6 & 15.4 \\
\hline $2016-17$ & 2.7 & 12.8 & 15.5 & 2.6 & 11.2 & 13.8 \\
\hline \multicolumn{7}{|c|}{ Source: Central Statistics Office } \\
\hline
\end{tabular}

According to the table, the public sector's share ranges from 2.1 to 2.8 percent, while the private sector's proportion spans from 12.8 to 15.9 percent at 2011-12 prices throughout a seven-year period from 2011 to 2017.

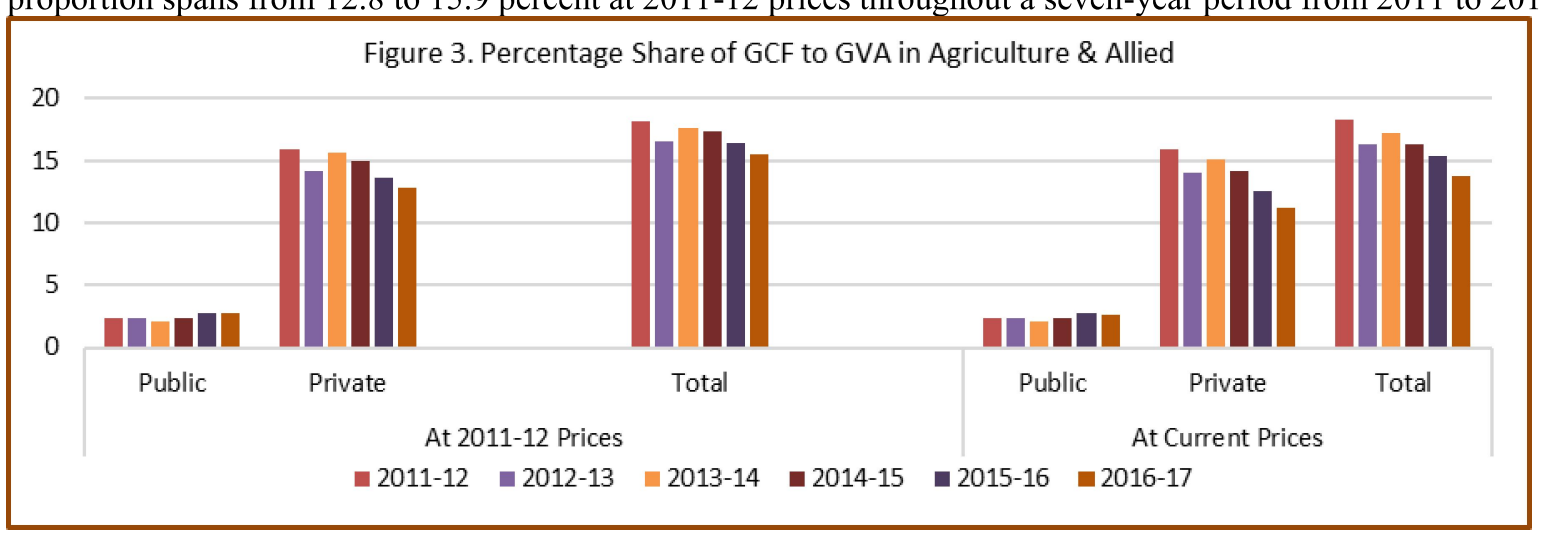

The total column is reflected within that case. On the other hand, the public sector's performance in terms of the percentage contribution of GCF to GVA at current prices is the same as it was in 2011-12. When compared to the values at 2011-12 prices, the private sector values are somewhat lower.

\subsection{Agricultural Land Holdings}

The size of landholdings in hectares is depicted in Table 5.

\begin{tabular}{|c|c|}
\hline \multicolumn{2}{|c|}{ Table 5. India's Average Farm-Size } \\
\hline Period & Average farm-size in hectares \\
\hline $1976-77$ & 2.00 \\
\hline $1995-96$ & 1.41 \\
\hline $2015-16$ & 1.08 \\
\hline \multicolumn{2}{|c|}{ Source: Agriculture Census, Census of } \\
India \\
\hline
\end{tabular}

It was observed that the average farm size of agricultural land has been shrinking. It was two hectares in 1976-77, down to 1.41 hectares in 1995-96 and by 2015-16 it was at 1.08 hectares.

\subsection{Fragmentation of arable land}

Further, the agricultural land is fragmented due to generations and no additions in the cultivable land and hence the result is fragmentation.

The details and classifications of landholdings are shown in Table 6. From 62.9 percent in 2000-01 to 64.8 percent in 2005-06, 67.1 percent in 2010-11, and 68.45 percent in 2015-16, the marginal land holdings (percentage) have grown. In India, marginal farmers accounted for $68.45 \%$ of all farmers in $2015-16$, with small farmers accounting for 17.62 percent, semi-medium 9.55 percent, medium 3.8 percent, and large farmers accounting for 0.58 percent.

\begin{tabular}{|l|c|c|c|c|c|}
\hline \multicolumn{6}{|c|}{ Table 6. Number and Area of Operation Land Holdings in India (\%) } \\
\hline \multicolumn{1}{|c|}{ Category } & $2000-01$ & $2005-06$ & $2010-11$ & $2015-16$ & Size (No of Hectare) \\
\hline Marginal & 62.9 & 64.8 & 67.1 & 68.45 & $<1$ hectare \\
\hline Small & 18.9 & 18.5 & 17.9 & 17.62 & 1 to 2 hectares \\
\hline Semi-Medium & 11.7 & 10.9 & 10.0 & 9.55 & 2 to 4 hectares \\
\hline Medium & 5.5 & 5.0 & 4.3 & 3.80 & 4 to 10 hectares \\
\hline Large & 1 & 0.8 & 0.7 & 0.58 & $>10$ hectares \\
\hline Total & 100.0 & 100.0 & 100.0 & 100.00 & \\
\hline \multicolumn{6}{|l|}{ Source: Extracted from Department of Agriculture, Cooperation \& Farmers Welfare Reports } \\
\hline
\end{tabular}


The same thing is visible in Figure 4 and farmers of large size holdings are disappearing (Less than one percent)

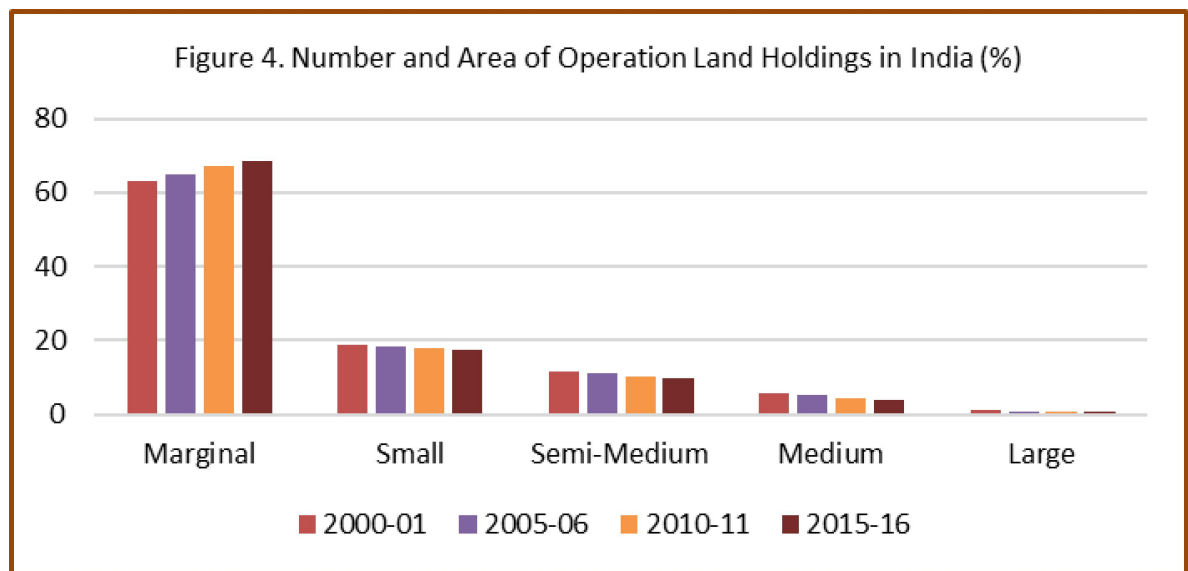

1.7 Share of Agriculture and Allied Sector in Employment and GDP

Most Indians rely on the industry for employment opportunities. From 69.9\% in 1951 to 43.21 percent in 2019 , the employment share has been decreasing.

\begin{tabular}{|c|c|c|c|c|c|c|c|c|}
\hline \multicolumn{9}{|c|}{ Table 7. Share of Agriculture in Employment and GDP (\% Share) } \\
\hline Decade & 1951 & 1961 & 1971 & 1981 & 1991 & 2001 & 2011 & 2019 \\
\hline Share in GDP & 51.9 & 46.3 & 40.5 & 35.4 & 28.5 & 22.4 & 14.4 & 14.6 \\
\hline Share in Employment & 69.9 & 69.5 & 69.7 & 60.5 & 59 & 58.2 & 54.6 & 43.21 \\
\hline
\end{tabular}

However, the decline in the share of GDP has been far greater than the decline in the share of employment, implying that most of the Indian population relies on agriculture for employment, even though the share of GDP has been rapidly declining, putting the country in a state of disguised unemployment. Figure 5 depicts the same in further detail.

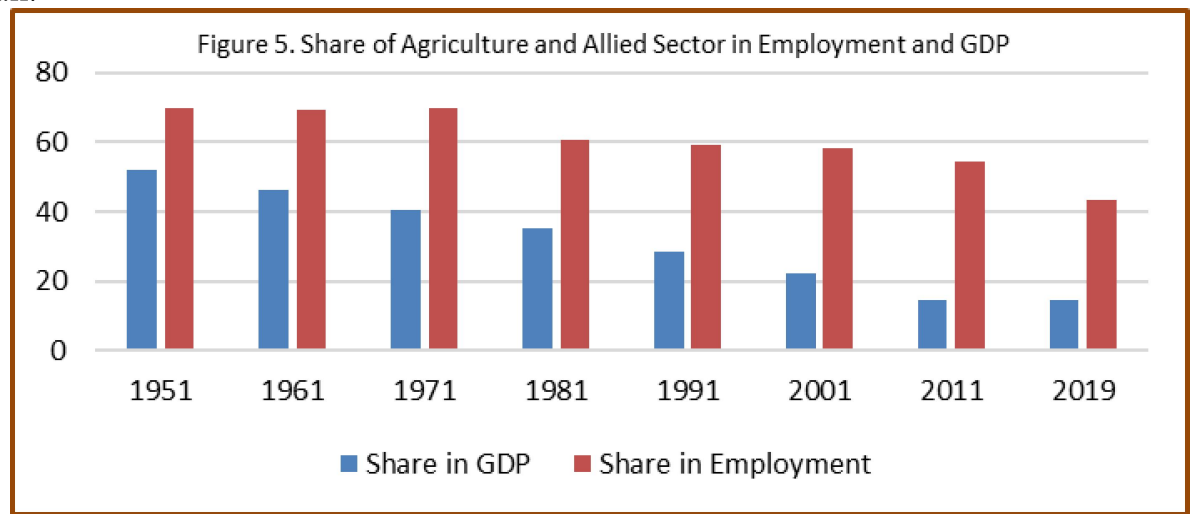

\subsection{Conclusion}

Agriculture employs 43.21 percent of India's workers and accounts for 14.6 percent of the country's GDP. The GVA of the primary sector fell progressively from 18.5 percent in 2011-12 to 17.2 percent in 2017-18, before rising to 20.2 percent in 2020-21.Agriculture investment accounts for less than 3\% of GDP. The government invests less than $1 \%$ of GDP on agriculture, but private investment ranges from 1.8 to 2.7 percent of GDP, with a negative trend. Agriculture (including associated sectors) accounts for a small part of gross fixed capital creation in India, and the amount has been dropping in recent years. A decline in the average farm size of agricultural land has been observed. The percentage of marginal land-holdings has risen from 62.9 percent in $2000-01$ to 68.45 percent in $20015-16$.

\section{REVIEW OF LITERATURE}

\subsection{Meaning of Agro-Processing}

Crop growth and harvesting, as well as livestock rearing and slaughter, are all part of primary food production. Milking, capturing fish and shellfish, and collecting hen eggs are some more examples. Vegetables, fruits, legumes/beans/pulses, grains, tubers, meat, milk, chicken, egg, fish, and other seafood are the basic dietary categories, sometimes known as 'food components (Eurostat 2017). 
Agro-processing may be defined as a series of technological economic operations that are carried out to preserve and handle agricultural output so that it can be used as food, feed, fiber, fuel, or industrial raw material. Inadequate attention to the agro-processing industry in the past harmed both the producer and the consumer, as well as the country's economy. Grinding groundnuts into peanut butter, pressing oil from vegetable seeds, pressing juice from fruit, creating cheese from milk, and manufacturing mincemeat are all instances of secondary processing (Puja Chadha, 2013).

\subsection{Review of Studies related to agro-processing industries in India}

India is the world's second-largest food producer, according to P.G. Chengappa (2004), and the food industry's expansion potential is enormous, considering the country's wide consumer base. The goal is to increase agroindustries' ability to convert a part of their output into value-added items that may be sold in domestic and international markets. This study looks at the current condition of agro-processing, as well as future trends and main issues.

Pardeep S. Shehrawat (2006) observed and advisedfor the successful operation of food processing and other agro-businesses, entrepreneurs face a multitude of challenges in finance, marketing, technology, and export. The provision of infrastructure that permit the establishment of commercially viable units is urgently required. Entrepreneurs should be armed with the most up-to-date technology and abilities by hosting a variety of entrepreneurial motivating and skill-building programs on a regular basis. For this research, a total of 120 entrepreneurs were interviewed by the researcher.

Fruit and vegetable processing showed the greatest rise in value (133 percent), followed by bread and confectionary facilities, according to Sharma KD, Pathania M S, and Lal H (2010). A company's size is directly proportionate to the number of backward and forward links it has. Among the findings and recommendations that arose from the investigation were a policy push and a focus on developing industrial sites in raw and material-producing regions.

According to Singh, P. K. (2010), the loss of grains in the godowns of the Food Corporation of India (FCI) lately aroused a great lot of worry, not only because of the wastage, but also because it occurred at a time when the government was discussing the National Food Security Act. The purpose of this essay is to examine all aspects of grain management in India and provide a complete solution to the problem. The proposed method might be explained and advocated in the context of mitigating current grain losses. To be profitable and sustainable, any grain management strategy must address issues such as decentralisation, decreased handling costs, greater rural community interaction, and self-sustaining frameworks.

Marwaha RS, et al (2010) stated that because of economic liberalisation, expanded market possibilities, and the development of indigenous processing variants, the Indian potato processing business has grown quickly. Potato chips, French fries, potato cakes or powder, and other processed goods are the four main divisions of the potato processing business. Currently, the structured and unorganized sectors handle around $4 \%$ of total potato production. Potato chips remain the most popular processed product, and securing a year-round supply of processing variants at competitive pricing remains a critical concern.

Singh SP, Tegegne F, and Ekenem E (2012) observed that India's agricultural basis is robust, but food waste is quite high and food processing is relatively low. India's proportion of processed food exports in global commerce has remained stable at around 1.5 percent ( $\$ 3.2$ billion). This article looks at the current state of the food processing sector, as well as the limits and issues that are holding it down.

Pratibha Tewari and B. L. Manjunatha (2014) found that horticultural produce consumption has expanded during the last two decades, both domestically and internationally. Between 2001/02 and 2011/12, fruit and vegetable output climbed by 80 and 69 percent, respectively. To avoid challenges to farming enterprises, the gap between farm gate and retail prices must be narrowed. In huge marketplaces when farmers do not make a profit, unprocessed horticultural produce is offered at a cheaper price.

Sanjeev Kumar et al (2017) reported that India is the world's greatest producer and the second-largest producer of fruits and vegetables, and it also has a strong processing history. Value addition in the agrarian sector has resulted in the possibility of alternative income options, risk reduction, a better proportion of the consumer's price, longer product shelf life, and so on. The overall picture of the food processing business is favourable, but we must also include waste from harvesting to consumption.

According to Ranjeet Kumar (2017), the food processing industry has considerable potential to boost India's rural economy by optimizing the use of local resources such as perishable agricultural commodities and surplus labor to create employment and reduce food waste. Bihar produces the fourth-largest number of agricultural surpluses in India;however it lags behind in food processing. The purpose of this research is to gain a better understanding of the current situation and structure of the food processing sector in India as a whole, as well as in Bihar specifically.

Javaid, M. and Haleem, A. (2019) stated that in today's globalised society, additive manufacturing (AM) is critical since it enables revolutionary technology for producing bespoke parts. AM can design/produce 
customised food products including coffee, pizza, burgers, biscuits, cakes, chocolates, and other daily foods based on the number of ingredients, shape, and color requirements. With its capacity to build customized physical models and make them directly for use on farms, AM provides innovation to the agriculture sector.

\subsection{Review of Studies related to agro-processing industries in other countries}

John Connor, et al. (1985) predicted that though the rate of development in demand for processed food in India is slower than in industrialized countries, increasing urbanisation and per capita income have produced a need for processed food and hence a necessity for a well-established food processing sector.

Joel J Mmasa (2013) said thatIf Tanzania wants to thrive and gain from the agriculture industry, value addition techniques for agricultural products are critical. Small-scale farmers' livelihoods are significantly improved by value addition. Despite its enormous potential, the industry is confronted with a variety of obstacles, including low productivity, little output quality, and low contribution to national socio-economic goals; underutilization of existing resources, and restricted market and value addition opportunities.

\subsection{Summary of the literature review}

India is the world's second-largest producer as well as consumer of fruits and vegetables. Agro-processing is a collection of technological economic operations that retain and treat agricultural output so that it can be used as food, feed, fiber, fuel, or industrial raw material. Inadequate attention paid to the agro-processing business has damaged both farmers and consumers, as well as the country's economy. Potato chips remain the most popular processed food, and guaranteeing a year-round supply is critical. Using additive manufacturing, customised food goods such as coffee, pizza, burgers, biscuits, cakes, and chocolates may be developed and made.The food processing industry in India has enormous potential to boost the country's rural economy. Despite its immense potential, Tanzania's food processing industry faces several challenges, including low productivity, poor output quality, and a lack of contribution to national socio-economic goals. Value addition strategies for agricultural goods are vital if Tanzania wishes to flourish and profit from the agriculture business.

Though the rate of growth in demand for processed food in India is slower than in developed nations, scholars believe that rising urbanisation and per capita income have created a need for food processing.

\section{PROBLEM STATEMENT}

Agriculture employs the highest (43.21) percent of India's workers and accounts for the lowest (14.6) percent of the country's GDP. The GVA of the primary sector fell progressively from 18.5 percent in 2011-12 to 17.2 percent in 2017-18. Moreover, the sector suffers from several challenges, such as low productivity and poor output quality. However, India's food processing industry has enormous potential to boost the country's rural economy. Value addition solutions for agricultural commodities are necessary for the agriculture sector to thrive and profit. The researcher gives an attempt to address this issue and trace out possibilities of value addition.

\section{OBJECTIVES OF THE RESEARCH}

The following are the research paper's objectives:

4.1 Investigate and comprehend the current state of Indian agriculture.

4.2 Examine the underlying causes of unproductive Indian agriculture.

4.3 To do a literature review on lucrative agricultural or farm management strategies.

4.4 Creating a value-added programme to make Indian agriculture a successful enterprise.

\section{RESEARCH METHODOLOGY}

The data utilized in the study is secondary data. All published data from the Department of Agriculture, Ministry of Agriculture, and RBI bulletin, among other sources. The name of the source is indicated at the bottom of the statistical tables included in the study. To conduct a review of literature, published research papers on the subject are evaluated.Data is classified and tabulated in cross tables, with years in the rows and columns as needed and available (from the sources) to meet the study objectives.Most of the data is presented in percentage analysis and diagrammatic representations are done in bar charts wherever needed for better comprehension of the subject.

\section{RESEARCH FINDINGS AND IMPLICATIONS}

The agriculture and industrial sectors are interconnected through food processing. It contributes to a reliable supply of safe and nutritious food at reasonable prices for the whole population. Most of agricultural goods are unfit for human consumption in their natural state, thus they are processed. Wheat is made into flour, paddy into rice, sugarcane is made into jaggery, and sugar, ethanol, and alcohol are all made from sugarcane. These goods, such as flour, can be further processed into bread. Aside from that, leftover parts of the crop, such as risk husk, may be processed to produce valuable products, like flour. For electricity cogeneration, rice bran oil, cow feed, and sugarcane bagasse can be utilized.Food grain processing, fruit and vegetable products, milk and milk 
products, meat, and poultry products, and so on are all sub-sectors of the Indian food processing business.

\subsection{Food Grain Processing}

Rice, coarse cereals, maize, legumes, green gram, and black gram are among the food grains predicted to have record-high output levels in 2017-18.

\begin{tabular}{|l|c|c|c|c|}
\hline \multicolumn{5}{|c|}{ Table 8. Production of food grains and oilseeds during 2017-18 (in m tonnes) } \\
\hline Particulars & $\begin{array}{c}\text { Estimated } \\
\text { Production } \\
2017-18\end{array}$ & $\begin{array}{c}\text { Production in } \\
2016-17\end{array}$ & $\begin{array}{c}\text { Average Production in last } \\
5 \text { years }\end{array}$ & $\begin{array}{c}\text { Percentage YoY } \\
\text { increase/decrease }\end{array}$ \\
\hline Food Grains & 277.49 & 275.11 & 260.18 & 0.9 \\
\hline Rice & 111.01 & 109.7 & 106.29 & 1.2 \\
\hline Wheat & 97.11 & 98.51 & 93.34 & 3.4 \\
\hline $\begin{array}{l}\text { Coarse } \\
\text { Cereals }\end{array}$ & 45.42 & 43.77 & 41.7 & 3.5 \\
\hline Pulses & 23.95 & 23.13 & 18.85 & -4.5 \\
\hline Oil seeds & 29.88 & 31.28 & 29.54 & 3.8 \\
\hline \multicolumn{2}{|c|}{ Source - Department of Agriculture Cooperation and Farmers Welfare } \\
\hline
\end{tabular}

Between harvest and consumption, cereals go through a series of processing processes. Cleaning, grading, hulling, milling, pounding, grinding, tempering, parboiling, soaking, drying, and screening are some of the processes. Primary processing products are still unfitted for human consumption. Fermentation, baking, puffing, flaking, frying, and extrusion are examples of secondary processing. Segments of the food processing industry and products produced in India through the value addition process are depicted in Table 9.

\begin{tabular}{|l|l|}
\hline \multicolumn{2}{|c|}{ Table 9. Segments of food processing industry and products produced in India } \\
\hline Sectors & Products \\
\hline Dairy & $\begin{array}{l}\text { Whole milk powder, skimmed milk powder, condensed milk, ice cream, butter and ghee, } \\
\text { cheese }\end{array}$ \\
\hline Fruits \& Vegetables & $\begin{array}{l}\text { Beverages, juices, concentrates, pulps, slices, frozen \& dehydrated products, potato } \\
\text { wafers/ chips, etc }\end{array}$ \\
\hline Grains \& Cereals & $\begin{array}{l}\text { Flour, bakeries, starch glucose, cornflakes, malted foods, vermicelli, beer and malt } \\
\text { extracts, grain-based alcohol }\end{array}$ \\
\hline Fisheries & Frozen canned products mainly in fresh form \\
\hline Meat \& Poultry & Frozen and packed -mainly in fresh from egg powder \\
\hline Consumer Foods & Snack food, namkeens, biscuits, ready to eat food, alcoholic and non-alcoholic beverages \\
\hline \multicolumn{1}{|c|}{ Source: Ministry offood processing, GoI, Annual report, 2004; Singh et al. 2012 } \\
\hline
\end{tabular}

Exports of APEDA (Agricultural and Processed Food Products Export Development Authority)products are shown in Table 10 as a proportion of overall exports for the last five years, from 2016-17 to 2020-21.

\begin{tabular}{|c|l|c|c|c|c|c|}
\hline \multicolumn{2}{|c|}{ Table 10. India's Export of APEDA Product during 2016 - 21 } \\
\hline \multirow{2}{*}{ S. No } & \multicolumn{1}{|c|}{ APEDA Product } & $\begin{array}{c}\text { \% Share Share } \\
2016-17\end{array}$ & $\begin{array}{c}\text { \% Share } \\
2017-18\end{array}$ & $\begin{array}{c}\text { \% Share } \\
2018-19\end{array}$ & $\begin{array}{c}\text { \% Share } \\
2020-21\end{array}$ \\
\hline 1 & Non-basmati Rice & 14.9 & 18.3 & 15.7 & 12.1 & 23.2 \\
\hline 2 & Basmati Rice & 18.9 & 21.4 & 24.3 & 25.9 & 19.4 \\
\hline 3 & Buffalo Meat & 23.0 & 20.7 & 18.6 & 19 & 15.3 \\
\hline & Total & $\mathbf{5 6 . 8}$ & $\mathbf{6 0 . 4}$ & $\mathbf{5 8 . 6}$ & $\mathbf{5 7}$ & $\mathbf{5 7 . 9}$ \\
\hline 4 & Miscellaneous Preparations & 2.3 & 2.3 & 3 & 3.5 & 3.8 \\
\hline 5 & Groundnuts & 4.8 & 2.7 & 2.4 & 4.3 & 3.5 \\
\hline 6 & Cereal Preparations & 3.1 & 2.8 & 2.9 & 3.2 & 3.1 \\
\hline 7 & Maize & 0.9 & 1.8 & 1.4 & 0.9 & 3.1 \\
\hline 8 & Wheat & 0.4 & 0.5 & 0.3 & 0.4 & 2.7 \\
\hline 9 & Processed Vegetables & 2.0 & 1.8 & 1.8 & 2.3 & 2.4 \\
\hline 10 & Processed Fruits, Juices \& Nuts & 2.2 & 2.1 & 2.1 & 2.6 & 2.1 \\
\hline 11 & Cashew Kernels & 4.6 & 4.7 & 3.4 & 3.4 & 2 \\
\hline 12 & Fresh Onions & 2.7 & 2.5 & 2.6 & 1.9 & 1.8 \\
\hline 13 & Jaggery \& Confectionery & 1.3 & 1.1 & 1.2 & 1.4 & 1.7 \\
\hline 14 & Alcoholic Beverages & 1.7 & 1.7 & 1.6 & 1.4 & 1.6 \\
\hline 15 & Fresh Grapes & 1.6 & 1.5 & 1.7 & 1.8 & 1.5 \\
\hline
\end{tabular}


According to table 10, the top three export items, basmati rice, non-basmati rice, and buffalo meat, account for more than half of the entire export value each year.

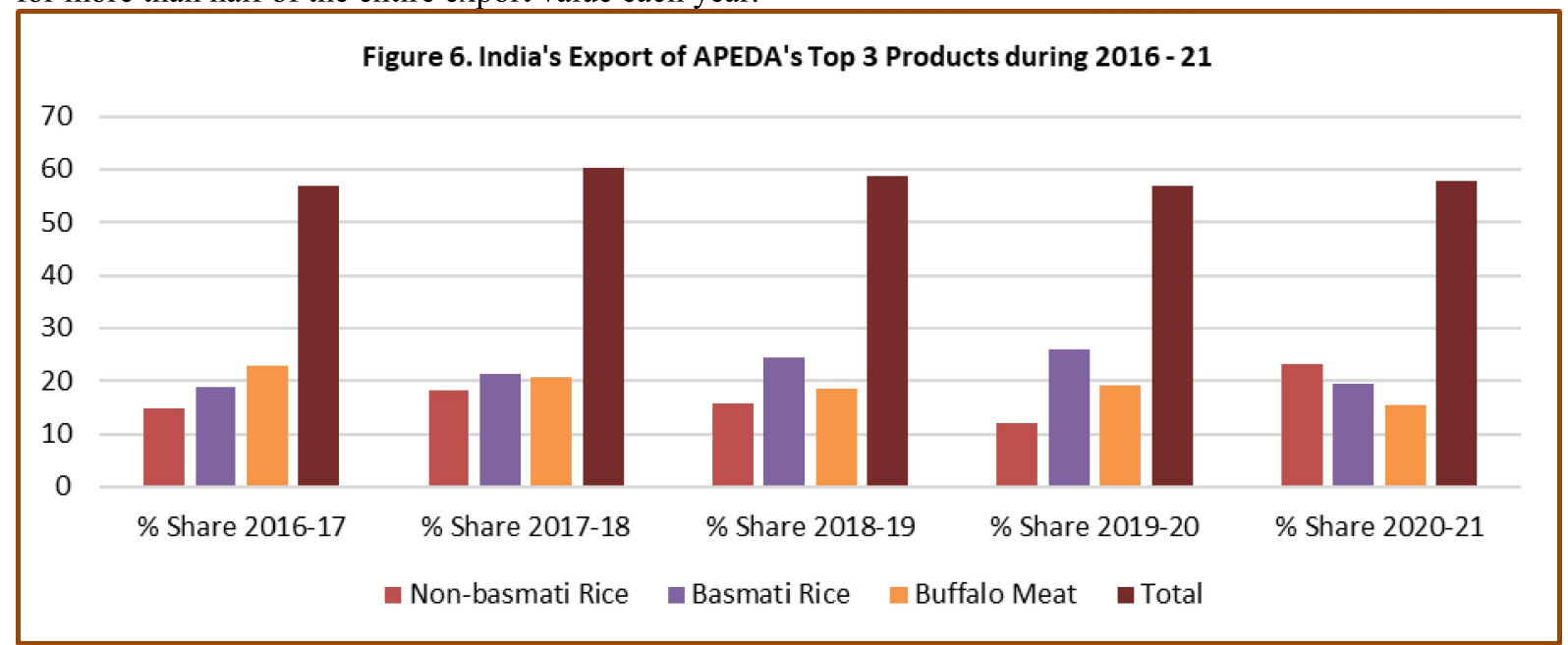

Figure 6 shows a bar chart of the top three exported items during the last five years. The percentage of nonbasmati rice exported has grown and was the highest in 2020-21, followed by basmati rice and buffalo meat.However, there is cause for concern because only three commodities account for more than half of the overall export value. There is a need to focus on other product exports as well, which will necessitate valueadded process innovation.Many commodities, for example, must be turned into'ready to cook' and'ready to eat' using simple techniques that ensure the preservation of vitamins, proteins, and other nutrients.

\section{SUGGESTIONS}

Marginal land holdings are major in number in India and most of the farmers do not like in the concepts like cooperative farming to grow the crops in large scale to reap the benefits of the scale. However, the following suggestions are being put forth for the benefit of the Indian farmers:

7.1 The need of thorough research in agriculture value addition

In general, the private sector's contribution to GCF and GVA is decreasing. This necessitates a thorough research in order to suggest a comprehensive solution scheme to vigorously push value addition processes in order to ensure that GCF occurs on a regular basis.

7.2 Attract private investment in agriculture

Agriculture investment by the government is less than 1\% of GDP, whereas private investment ranges from 1.8 to 2.7 percent of GDP, with a downward tendency. This means that the agriculture industry is unappealing to private investors, who are unsure whether their investment will be recovered. By the offer of incentives in the form of free power or substantial concessions, subsidised land for the erection of agro-processing plants in the clustered areas to process the vegetables and fruits.

7.3 Create and develop GCF through increased GVA

When agriculture's GVA rises, there is opportunity for and a need for value addition in the agricultural sector, based on the strengths of the goods that are abundantly grown and sold as raw rather than processed to add value and maximise export potential. This is only achievable if agricultural colleges and industrial development centres (IDC) work together to support, lead, train, and mentor young people in the creation of small-scale agroprocessing facilities. This provides local villages with work opportunities, making it a win-win situation for the development and success of rural industrial development.

7.4 Value addition by multiple cropping

Multiple-Cropping: In this approach, farmers produce two or more crops on agricultural land in a single calendar year while employing rigorous input management strategies. Inter-cropping, mixed-cropping, and sequence cropping are all examples of it. Multiple cropping systems allow for more effective use of resources such as sunshine, nutrients, and water, resulting in improved biological variety and production stability. Because the components of the system have distinct fertilizer and moisture requirements, intensive cropping systems using crop mixers were effective.

\subsection{Value addition through Diversification}

Diversification is critical in reducing the risks connected with farming. It includes not only various crops but also various businesses. This involves the production of fruits, flowers, and vegetables, as well as animal husbandry, sericulture, and apiculture, among other things. Aside from providing a strong return on investment, they are ideal for tiny farmers with limited resources. They have the benefit of adding value to things, which commands a good consumer price 


\subsection{Value Addition by multi-layer farming}

Multilayer cropping refers to the practise of growing plants of varying heights in the same field at the same time. It is the process of cultivating many crops of various heights, rooting patterns, and duration concurrently. The goal of this multi-layer cropping scheme is to make better use of vertical space.Multi-layer cropping can boost output and revenue while also providing additional benefits such as higher crop diversity, improved agricultural system functioning, spare land for biodiversity or other purposes, and lower use of inorganic fertiliser and pesticides.

\subsection{Vegetables and Fruits processing}

According to World Health Organization (WHO) estimates, insufficient fruit and vegetable consumption caused 3.9 million deaths globally in 2017. Consuming fruits and vegetables as part of a daily diet may lower the risk of some NCDs, such as cardiovascular disease and cancer (WHO, 2019). Inadequate fruit and vegetable consumption is the cause of $14 \%$ of deaths from gastrointestinal cancer, $11 \%$ of deaths from ischemic heart disease, and $9 \%$ of deaths from stroke worldwide (Afshin et al., 2019).

Sorting, grading, shipping, wholesaling, and retailing, as well as processing and other agri-food-related operations, are all examples of value addition for fresh fruit and vegetables. Some performers play many roles, such as: wholesalers, for example, may play a significant role in supplying growers with market information and handling postharvest logistics. Although supermarkets are gaining market share in many countries, the traditional sector remains critical for fruit and vegetable retailing and food security in low-income nations(Parfitt et al., 2010).

Improving the sector's competencies can improve market transparency as well as the quality and safety of food available on domestic markets (Demmler, 2020). Furthermore, these midstream agri-food firms provide farmers the greatest domestic market potential (AGRA, 2019).Fruits and vegetables go through active biological processes such as respiration, ripening (fruits), and senescence after being harvested. Sugar levels drop and starch forms during storage, resulting in a loss of flavour and texture. For example, potatoes with a high sugar content may generate Maillard browning reactions during processing, particularly when drying and frying. The opposite response is undesirable in mature sweet corn because it results in a loss of flavor and texture.

\begin{tabular}{|l|l|l|}
\hline \multicolumn{3}{|c|}{ Table 11. Value Addition Potential of Arid Fruits } \\
\hline Arid Fruits & \multicolumn{1}{|c|}{ Value Added Products } & \multicolumn{1}{|c|}{ Income Profit Margins } \\
\hline Ber & Preserve, candy and squash & $40-60 \%$ \\
\hline Kachra & Melosip, traditional drying & $60-70 \%$ \\
\hline Ker & Dried fruits, pickle & Up to $80 \%$ \\
\hline Khejri pods & Dried Sangri & $40-60 \%$ \\
\hline Amla & Jam, candy, preserve, pickle & $50 \%$ \\
\hline Bel & Squash & $50-60 \%$ \\
\hline Pomgranate & Squash and anardana & $40-50 \%$ \\
\hline Carrot & Fresh Juice & Up to 200\% \\
\hline \multicolumn{2}{|l}{ Source: Pratibha Tewari and B. L. Manjunatha (2014) } \\
\hline
\end{tabular}

Table 11 shows the breadth of possibilities for value addition as well as predicted profitability margins for desert fruits. (Pratibha Tewari and B. L. Manjunatha 2014).

Bananas are a type of starchy fruit that may be fried and eaten as a snack. Heat destroys enzymes and microbes, while moisture removal avoids contamination. Moisture-proof, light-proof, and air-tight containers can be used to pack products with a long shelf life. The main cause of degradation is the rancidity of the frying oil that remains on the product.Banana powder offers a wide range of uses in Ayurvedic medicinal formulations, with a profit margin of more than 200 percent.

Dried fruits, vegetables, herbs, and spices are low-volume, high-value commodities that may be profitable for small-scale manufacturers if there is adequate demand. Drying fruits and vegetables preserves them because it removes the bulk of the water that enzymes and bacteria need to spoil them. However, if the drying circumstances are not properly controlled, drying might result in undesirable color, flavor, and texture alterations. 7.8 Integrated farming techniques

Innovative techniques of forming have emerged, such as hydroponic and aquaponic, which attempt to produce more yield with less land by using greenhouses and poly houses to adjust the temperature of the grown area. Aquaponics includes transferring water from aquacultures to plants after eliminating ammonia and then returning the water to aquaculture. This is referred to as integrated farming.

7.9 Focus on shared farming

Land, labor, equipment, tools, seeds, fertilizers, pesticides, animals, and other farm inputs may be shared or rented out by farmers to make farming more affordable for everyone. A person or a group of farmers can make these arrangements. This can also be addressed through microfinance, resulting in lower interest rates and the ability to be maintained by educated young who have been taught in the use of the equipment. 


\subsection{Need of contract farming}

The future of contract farming in India is brightening, due to a growing middle-class population concerned about food safety and quality. Contract farming, which provides farmers with market certainties while maintaining supply to traders, might be a feasible answer to the current situation (Ramnath K. Ray et al. 2020). The government should establish a monitoring mechanism and a dispute resolution body to ensure that both parties adhere to the contract's conditions.

7.11 Focus to farm rare grains, veggies, and fruits

Prioritized quality-driven manufacturing in order to pursue export opportunities and increase income. Rare fruits and vegetables such as red and yellow capsicum, yellow watermelon, dragon fruits, Israeli dates, blood lime (red-lime), and others are in high demand abroad. Farmers can be informed on what can be cultivated based on their soil conditions, allowing them to optimize their revenue. Similarly, millets such as Kodo millets, foxtail millets, finger millets, and other millets are well-known for their purposes. Because of the health advantages, one kilogram of Kodo millets is sold for Rs.100 (more than rice or wheat but at a lower cultivation cost than paddy or wheat).

\subsection{Focus on Productivity increase}

When compared to productivity in agriculture of other nations, India is far lagging as is depicted in Figure 7. It is revealed that India is far behind from other nations with respect to major food crops like paddy, wheat, pulses, and other cereals.Adopting low-cost and no-cost technology includes organic farming, integrated farming, micro irrigation, and precision farming, which are all at zero or insignificant cost but productivity will be substantially high.

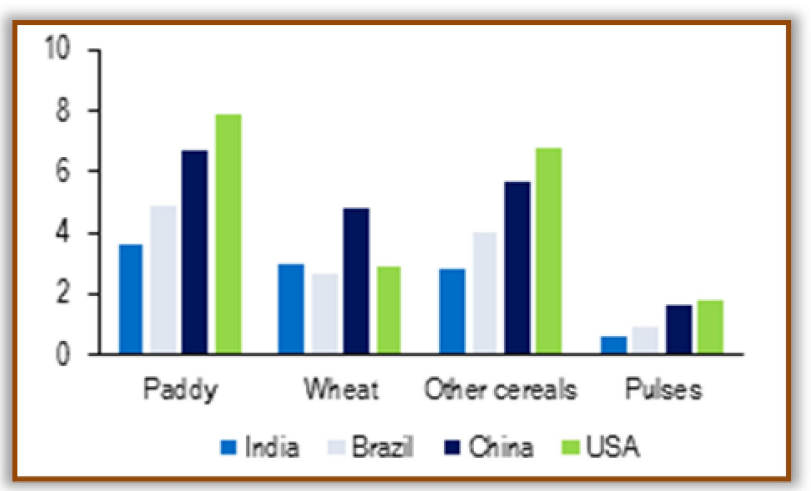

Figure 7: Yield in different countries (tonne/ha) 2014-15

Sources: Food and Agriculture Organization of the United Nations; PRS.

On the other hand, farmers in traditional agriculture employ animals instead of equipment, and they produce, harvest, and market their products using more primitive techniques and hence yield will be lower. Farmers in contemporary agriculture, on the other hand, employ hybrid seeds of the same plant (created through biotechnology), technologically improved equipment, and pesticides, among other things.

\section{CONCLUSION}

The planet Earth is a marvel. Humans cultivate a wide range of crops. Small nations like Israel, Germany, the Netherlands, and Denmark have produced miracles by cultivating crops with the highest yield per hectare on the earth. Table 12 shows the yields of some of the crops cultivated in both the Netherlands and India. 


\begin{tabular}{|c|c|c|c|}
\hline \multicolumn{4}{|c|}{ Table 12. The Agriculture Miracle: Netherlands Vs India } \\
\hline Particulars & Netherlands & India & World Average \\
\hline Land Sq. KM & 17960 & 1797210 & \\
\hline$\%$ Of Agri Land & 53.3 & 60.4 & \\
\hline \multicolumn{4}{|c|}{ Wheat Production in tones 2017} \\
\hline World Rank & 3 & 52 & \\
\hline Yield ton/Hectare & 9.1 & 3.2 & 3.4 \\
\hline \multicolumn{4}{|c|}{ Tomato Production in Tones 2017} \\
\hline World Rank & 1 & 88 & \\
\hline Yield ton/Hectare & 508.4 & 26 & 55.3 \\
\hline \multicolumn{4}{|c|}{ Potato Production in tones 2017} \\
\hline World Rank & 6 & 46 & \\
\hline Yield ton/Hectare & 62 & 22.3 & 20.5 \\
\hline \multicolumn{4}{|c|}{ Onion Production in tones 2017} \\
\hline World Rank & 4 & 101 & \\
\hline Yield ton/Hectare & 75.4 & 17.2 & 26.6 \\
\hline
\end{tabular}

In terms of size and fertile land, India is 100 times larger than the Netherlands. However, the Netherlands is ranked third in wheat output, while India is ranked 52nd. The Netherlands produces wheat three times more per acre than India. India is far away from the Netherlands in terms of tomato, potato, and onion production. Indian farmers must continue to develop and learn in order to keep up the yield and productivity with Dutch farmers. India may benefit from countries such as Thailand, which has one of Southeast Asia's most advanced food processing sectors. There are around 10,000 food and beverage processing plants in the country. This is the result of the following paradigm developments in that nation:

i) A shift toward high-value products;

ii) An increase in internal demand for safe and healthy food;

iii) The emergence of national brands and the growth of large-scale distributors;

iv) The rapid rise of foreign retailers giving huge scope for the exports;

v) Rising intra-ASEAN (Association of Southeast Asian Nations) food trade;

vi) Contract farming; and

vii) Vertical integration of food producers.

Implementing some of these changes will improve the sector's performance and, as a result, its contribution to GDP will be larger.

\section{SCOPE FOR FUTURE RESEARCH}

The following are some of the research topics that have been suggested for further study:

9.1 Approaches to agricultural value addition in third-world countries

9.2 An investigation into the best agricultural value-added practises in advanced economies

9.3 A study of successful small and marginal farmers, as well as insights into their success.

9.4 Analytical assessment of Padma Sri Palekar's contribution to the Indian farming sector's value addition.

\section{BIBLIOGRAPHY}

Afshin, A., et al. (2019). Health effects of dietary risks in 195 countries, 1990-2017: A systematic analysis for the Global Burden of Disease Study 2017. The Lancet 393(10184):1958-72. www.thelancet.com/article/S0140- 6736(19)30041-8/full text.

AGRA. (2019). The hidden middle, a quiet revolution in the private sector driving agricultural transformation. www.agra.org/wpcontent/uploads/2019/09/AASR2019-The-Hidden-Middleweb.pdf

Chengappa, P.G., (2004). Emerging trends in agro processing in India. Indian Journal of Agricultural Economics. 59(1): 55-74.

Consultation Paper on IDEA (2021). Transforming Agriculture. IDEA (India Digital Ecosystem of Agriculture. Dept of Agrivulture, Cooperation and farmers' Welfare, Government of India. Pp. 1-57

Demmler, K.M. (2020). The role of small and medium-sized enterprises in nutritious food supply chains in Africa. WorkingPaper Series 2. GAIN, Geneva. doi.org/10.36072/wp.2

Eurostat (2017). Output of the agricultural industry, EU-28, 2016.

Javaid, M. and Haleem, A. (2019). Using additive manufacturing applications for design and development of food and agricultural equipment. International Journal of Materials and Product Technology. 58 (2/3): 225-238.

Joel J Mmasa (2013). Value Addition Practices to Agricultural Commodities in Tanzania-challenges.CLKnet 
Policy Brief No 20.

John Connor, et al (1985). Economic Forces Shaping the Food-Processing Industry. American Journal of Agricultural Economics. Agricultural and Applied Economics Association. 67(5): 1136-1142.

Marwaha RS, et al (2010). Potato processing scenario in India: industrial constraints, future projections, challenges ahead and remedies-A review. Journal of Food Science Technology 47(2): 137-156.

Pardeep S. Shehrawat (2006). Agro processing industries --- a challenging entrepreneurship for rural development. Journal of Asia Entrepreneurship and Sustainability. 11 (3): 1-15.

Pratibha Tewari and B. L. Manjunatha (2014). Priorities for Value Addition and Processing in Indian Agriculture. Pp: 103-113. https://krishi.icar.gov.in/jspui/handle/ 123456789/19662

Puja Chadha (2013). An Economic Analysis of Agro-Processing Industries in Himachal Pradesh. PhD thesis submitted to Dept of Economics, Himachal Pradesh University, Shimla.

Ramnath K. Ray et al. (2020). Problem and Prospect of contract Farming in India. Food and Scientific Reports. 1 (8): $63-68$

Ranjeet Kumar (2017). Status and growth potential of food processing industry in India: A case study of tsihar. Journal of Social and Economic Studies. 27 (2): 33-50.

Sanjeev Kumar et al (2017). Role of Value-addition in Agrarian Farming System in Enhancing the Farmer's Income. Indian Journal of Ecology. 44 (6): 909-913.

Sharma KD, Pathania MS and Lal H (2010). Value chain analysis and financial viability of agro-processing industries in Himachal Pradesh. Agricultural Economics Research Review. 23: 515-522.

Singh, P. K. (2010). A Decentralized and Holistic Approach for Grain Management in India. Current Science. 99 (9):1179-1180.

Singh SP, Tegegne F and Ekenem E (2012). The food processing industry in India: challenges and opportunities. Journal of Food Distribution Research. 43(1): 88-89.

$\mathrm{WHO}(2019)$. Increasing fruit and vegetable consumption to reduce the risk of non-communicable diseases. $e$ Library of Evidence for Nutrition Actions (eLENA). www.who.int/elena/titles/fruit_vegetables_ncds/en/\# 